\title{
Sugar Beet Cultivar Evaluation for Storability and Rhizomania Resistance
}

\author{
Carl A. Strausbaugh and Imad Eujayl, USDA-ARS NWISRL, 3793 North 3600 East, Kimberly, ID 83341; \\ Eugene Rearick, Amalgamated Research, Inc., Twin Falls, ID 83301; and Paul Foote and Dave Elison, Amalga-
} mated Sugar Co., 50 S. 500 W., Paul, ID 83347

\begin{abstract}
Strausbaugh, C. A., Eujayl, I., Rearick, E., Foote, P., and Elison, D. 2009. Sugar beet cultivar evaluation for storability and rhizomania resistance. Plant Dis. 93:632-638.

To reduce storage losses and improve resistance to rhizomania caused by Beet necrotic yellow vein virus (BNYVV), studies were initiated to establish a storage cultivar selection program. In 2006 and 2007, 30 or more commercial sugar beet (Beta vulgaris) cultivars were grown in soil naturally infested with BNYVV. At harvest, two root samples from each plot were collected and used to establish percent sugar. Additional samples were placed on top of an indoor pile (set point $1.7^{\circ} \mathrm{C}$ ) and inside an outdoor pile in a randomized complete block design with four replications. After 142 and 159 days in indoor storage, sucrose reduction ranged from 13 to $90 \%$ in 2007 and 57 to $100 \%$ in 2008 . Outdoor storage sucrose reduction ranged from 13 to $32 \%$ in 2007 and 28 to $60 \%$ in 2008 . An average of 31 and $45 \%$ of the root surface was covered with fungal growth in 2007 and 2008, respectively. Cultivars that retained the most sucrose had resistance to BNYVV and the least fungal growth and weight loss. Indoor storage with BNYVVinfested roots allowed for the most consistent cultivar separation and will potentially lead to selection of cultivars for improved storability and rhizomania resistance.
\end{abstract}

Controlling the loss of sucrose during sugar beet storage has been an industry goal since the 1950s (11). In Idaho, sugar beet (Beta vulgaris L.) roots may be stored up to 160 days, allowing weather (primarily temperature and moisture) and microbes to negatively influence the sucrose stored in the roots, along with normal respiration and the buildup of impurities $(3,5,6,9,34)$. Other factors can also influence sucrose loss such as scalping, impacts, and wounding during harvest and transport, mud and weeds in piles, and unusually high or low temperatures $(2,6,10,13,16,19,33)$. Disease and drought stress during crop production may also predispose the roots to sucrose loss in storage $(8,14,15,27,28)$. Rhizomania $(8,28)$, curly top (27), Rhizoctonia root rot (15), Aphanomyces root rot (7), and Cercospora leaf spot (24) during crop production have all been shown to lead to increases in sucrose loss in storage.

Rhizomania, caused by Beet necrotic yellow vein virus (BNYVV), has been shown to be particularly damaging in storage; sucrose losses up to $94 \%$ have been documented (28). Since BNYVV was first discovered in the United States in 1984,

Corresponding author: Carl A. Strausbaugh E-mail: Carl.Strausbaugh@ars.usda.gov

Accepted for publication 17 February 2009.

doi:10.1094/PDIS-93-6-0632

This article is in the public domain and not copyrightable. It may be freely reprinted with customary crediting of the source. The American Phytopathological Society, 2009. the virus has spread through the major U.S. production areas $(21,22)$. Currently, disease control for rhizomania largely relies on a single dominant gene, Rzl $(21,22)$. However, resistance breaking isolates that can overcome $R z l$ have been documented in some commercial fields $(1,17)$. Therefore, improving disease control for rhizomania and reducing storage losses will be important for maintaining factory efficiency and profitability. Selecting for resistance to BNYVV in cultivars is currently conducted through disease ratings and yield data collected from roots grown in field plots. This field approach is successful at identifying major gene resistance, but accurately selecting for the effects of minor genes is problematic. Cultivar selection for storability, although tried by some groups over recent decades, has also proven to be a challenge. In order to establish a cultivar selection approach for storability and improve on the selection for rhizomania resistance, investigations with rhizomania-infested sugar beet roots produced and stored under commercial conditions were conducted in indoor and outdoor piles.

\section{MATERIALS AND METHODS}

Treatments. Thirty-two commercial sugar beet cultivars were evaluated in 2006 to establish a screen for storability. The study was repeated in 2007 with 30 commercial sugar beet cultivars. Twenty of the cultivars were the same in both studies; whereas the others varied because of availability. All the cultivar names were coded ( $\mathrm{B}=$ Betaseed Inc., $\mathrm{C}=\mathrm{ACH}$ Seed Inc., $\mathrm{HH}=$ Holly Hybrids, $\mathrm{HM}=$ Hilleshog, and
$\mathrm{SX}=$ Seedex); respective companies can be contacted using the code to gain additional information on the cultivars. Cultivars contained at least the $R z 1$ gene for resistance to BNYVV except for the susceptible check, HM070005, and five cultivars (B-16, HM070011, HM070021, SX001, and SX004) evaluated in 2006. Rhizomania was uniform and evident throughout the naturally infested commercial fields in both years based on foliar and root symptoms and enzyme-linked immunosorbent assay (ELISA) (data not presented). Other diseases were not evident in the fields, and the roots were free of visible root rot at harvest. Plots were arranged in a randomized complete block design with four replications as four-row plots 10.4 and $7.3 \mathrm{~m}$ long in 2006 and 2007, respectively, with rows $0.6 \mathrm{~m}$ apart. The plots were planted to a density of 352,123 seeds/ha and thinned to 117,374 plants/ha. The fields were managed using standard commercial cultural practices. At harvest, three 8-beet samples were collected in nylon mesh onion bags from each plot. For six cultivars, an additional 8-beet sample was pulled at the same time for testing under ambient conditions outdoors. All storage samples (including the outdoor samples) were held inside the commercial storage building set to hold $1.7^{\circ} \mathrm{C}$ (building cooled with ambient air) until the indoor and outdoor commercial piles were established. The indoor samples were then placed on top of a 9.1-m-high commercial indoor pile in the center of the building while maintaining the samples in the same block design used in the field. The outdoor samples were placed inside a commercial outdoor sugar beet pile inside a metal corrugated ventilation pipe ( $0.9 \mathrm{~m}$ diameter) on top of plywood in the same experimental block design used in the field. The samples inside the pipe were 10 to $14 \mathrm{~m}$ from the edge of the pile. The open end of the pipe was covered with straw bales. The pipe was located on top of a $30-\mathrm{cm}$ layer of beet and was covered by roots to a height of $6.1 \mathrm{~m}$. The pile was ventilated using the same perforated pipe placed $3.7 \mathrm{~m}$ on center. The storage pipe with the samples was placed in between ventilation pipes. The roots surrounding the pipe were from commercial cultivars and healthy in appearance (no visible rhizomania or rot symptoms). Temperature was recorded at 1-h intervals on a Hobo temperature sensor (Model H08001-02; Onset Computer Corp., Bourne, MA) located in with the samples. 
2006 Samples. The trial was located in a commercial field $11.3 \mathrm{~km}$ north of Rupert, ID. The field had been in spring barley in 2005 and was planted to sugar beet on 10 April 2006. The plants were mechanically topped (leaving a $3-\mathrm{cm}$ diameter scar), and the center two rows were harvested on 6 October 2006 with a commercial harvester. The samples were placed inside the Twin Falls outdoor ventilated pile on 19 October. The indoor samples were placed on top of the pile on 20 October. On 26 February 2007, roots were retrieved after 142 days in storage.

2007 Samples. The trial was located in a commercial sprinkler-irrigated sugar beet field $4.8 \mathrm{~km}$ southeast of Rupert, ID where winter wheat was grown in 2006. The roots were mechanically topped (leaving a 3$\mathrm{cm}$-diameter scar), and the center two rows were collected with a commercial harvester on 27 September 2007. The samples were placed inside the Twin Falls outdoor ventilated pile on 17 October. The indoor samples were placed on top of the pile on 26 October. On 4 March 2008, roots were retrieved after 159 days in storage.

Rhizomania, fungal growth, and rot ratings. On 1 February each year, the indoor roots were visually evaluated while still lying on the storage pile for the percentage of surface area covered by primarily basidiomycete fungal growth (29). The outdoor samples were not rated for fungal growth because the fungal growth could not be evaluated without disturbing the samples inside the pipe. After samples were retrieved from the storage piles at the end of the storage period, the roots were evaluated for rhizomania symptoms using a 0 to 9 disease index where: $0=$ no symptoms; $1=$ root growth normal, minor bearding, and no discoloration; 2 = taproot slightly constricted and bearded; 3 = taproot moderately constricted, bearded, and discolored with very little adhering soil; 4 = similar to 3 except more adhering soil; $5=$ taproot wine-glass shaped, discolored, and brittle and feeder roots bearded with soil adhering; $6=$ damage to taproot severe with heavy bearding just below the crown; $7=$ taproot destroyed and severe bearding below the crown with root area a ball of soil; $8=$ similar to 7 except root necrotic into the crown area; and $9=$ root dead. The index was similar to one published previously (32) and was utilized in a continuous manner (all numbers between 0 and 9 possible) rather than categorically. At the same time, surface rot was also visually evaluated as the percentage of root area associated with discolored tissue such as dry black rot and/or wet bacterial rot.

Weight analysis. Prior to placing the storage samples in the pile, each sample was weighed. The samples were reweighed when retrieved from the storage pile. These weights were used to determine reduction in root weight.

Sugar analysis. Two samples collected from each plot at harvest were submitted to the Amalgamated Tare Lab in Paul, ID. Percent sugar was determined using an
Autopol 880 polarimeter (Rudolph Research Analytical, Hackettstown, NJ) and a half-normal weight sample dilution and aluminum sulfate clarification method (ICUMSA Method GS6-3 1994) (4). Conductivity was measured using a Foxboro conductivity meter Model 871EC (Foxboro, Foxboro, MA), and nitrate was measured using a multimeter Model 250 (Denver Instruments, Denver, CO) with Orion probes 900200 and 9300 BNWP (Krackler Scientific, Inc., Albany, NY).

Percent sugar for samples coming out of storage was determined by Amalgamated Research Inc., Twin Falls, ID using gas chromatography, because polarimeter readings can be affected by impurities that accumulate during storage. The gas chromatographic method was similar to ICUMSA Method GS4/7/8/5-2 (2002) with the following modifications: the internal standard used was D(-)-salicin[2(hydroxymethyl)phenyl- $\beta$-D-glucopyranoside, and equal volumes (to $\pm 0.01 \mathrm{ml}$ ) of a solution of internal standard in dimethylformamide were dispensed into weighed samples and standards using a volumetric dispenser (4). The gas chromatography analysis averaged $1.395 \%$ higher than the polarimeter reading on samples evaluated in previous work (28). To establish percent reduction in sugar at harvest versus storage, only samples from within the same plot were compared. Percent sugar reduction was established using the following equation: \% reduction in pounds of sucrose $=\left(1-\left\{\left[\left(\%\right.\right.\right.\right.$ sucrose $\left._{\text {storage sample }}-1.395\right) \times$
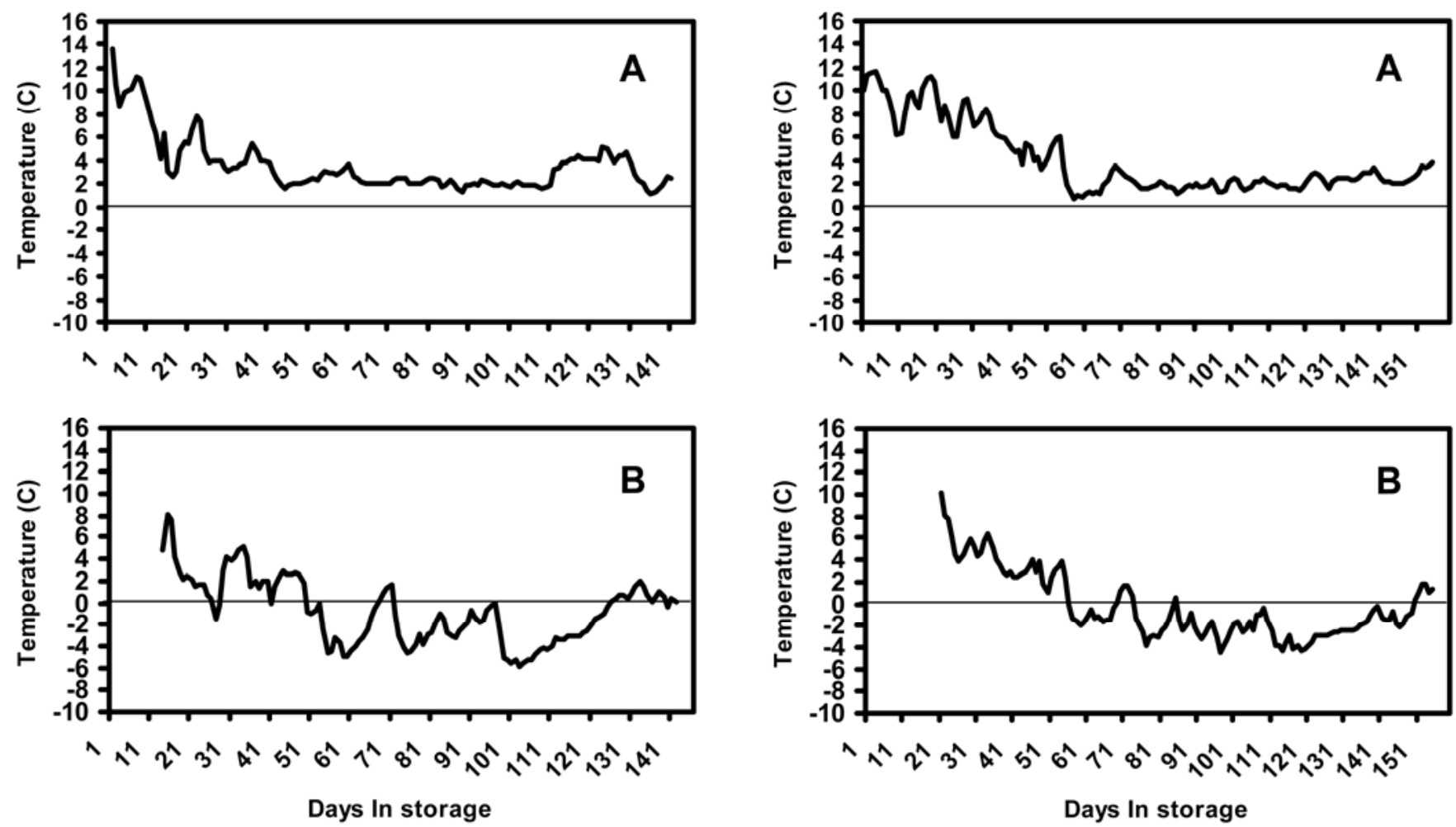

Fig. 1. Average daily temperature $\left({ }^{\circ} \mathrm{C}\right)$ during storage in commercial sugar beet piles from 6 October 2006 to 26 February 2007 in A, an indoor storage facility in Paul, ID, and $\mathbf{B}$, an outdoor pile in Twin Falls, ID.

Fig. 2. Average daily temperature $\left({ }^{\circ} \mathrm{C}\right)$ during storage in commercial sugar beet piles from 27 September 2007 to 4 March 2008 in A, an indoor storage facility in Paul, ID, and $\mathbf{B}$, an outdoor pile in Twin Falls, ID. 
weight $\left._{\text {storage sample }}\right] /\left(\%\right.$ sucrose $_{\text {harvest sample }} \times$ weight $\left.\left.\left._{\text {harvest sample }}\right)\right\}\right) \times 100$. Estimated recoverable sucrose $=$ extraction $\times 0.01 \times$ gross sucrose and extraction $=250+$ $[1255.2 \times($ conductivity -15000$) \times(\%$ sucrose -6185$)] /\{\%$ sucrose $\times[98.66-$ ( $7.845 \times$ conductivity)] $\}$.

Basidiomycete pathogenicity test. The pathogenicity test used roots of the cultivar B-16 that were produced on the USDA South Research Farm in Kimberly, ID using the Poncho Beta seed treatment (60 $\mathrm{g}$ a.i. clothianidin $+8 \mathrm{~g}$ a.i. betacyfluthrin/100,000 seed) and standard cultural practices (26). The plants had a very low curly top rating of 1 at the end of the growing season using a disease index (26) of 0 to 9 , where $0=$ healthy and $9=$ dead. No other disease or pest problems were evident on these plants. The plants were mechanically topped and harvested on 9 October 2007, and the roots were placed in a cold storage room at $3{ }^{\circ} \mathrm{C}$ and $90 \%$ relative humidity. All roots used in the pathogenicity test came from the same plot. The pathogenicity test consisted of 7 treatments: 6 basidiomycete isolates (F566, F568, F570, F574, F580, and F583) and an uninoculated check. Each sugar beet root served as an experimental unit. The roots were arranged in a randomized complete block design with five replications. Hyphal tipped cultures grown on Difco potato dextrose agar (PDA; Becton Dickinson \& Co., Sparks, MD) for 2 weeks at $21^{\circ} \mathrm{C}$ served as the source of inoculum. A 5-mm-diameter plug $12 \mathrm{~mm}$ in length was pulled from the shoulder of the root with a cork borer. Then, a 4-mm plug from the inoculum plate was placed into the hole and the plug reinserted. The root was placed on top of the indoor com-

Table 1. Disease and weight reduction data for 32 commercial sugar beet cultivars harvested in 2006 from a commercial field naturally infested with rhizomania in Paul, ID

\begin{tabular}{|c|c|c|c|c|}
\hline Cultivar $^{\mathrm{u}}$ & $\begin{array}{c}\text { Rhizomania } \\
\text { rating }^{\mathrm{v}}\end{array}$ & $\begin{array}{c}\text { Fungal growth } \\
(\%)^{\mathrm{w}}\end{array}$ & $\begin{array}{c}\text { Root rot } \\
(\%)^{\mathrm{x}}\end{array}$ & $\begin{array}{c}\text { Weight } \\
\text { reduction }(\%)^{y}\end{array}$ \\
\hline HH001 & $1.0 \mathrm{k}$ & $38 \mathrm{c}-\mathrm{h}$ & $36 \mathrm{a}-\mathrm{f}$ & $5.2 \mathrm{f}-\mathrm{k}$ \\
\hline B-23 & $1.2 \mathrm{jk}$ & $14 \mathrm{~h}-\mathrm{k}$ & $8 \mathrm{~g}$ & $4.9 \mathrm{~h}-\mathrm{k}$ \\
\hline B-27 & $1.2 \mathrm{jk}$ & $29 \mathrm{e}-\mathrm{k}$ & $30 \mathrm{a}-\mathrm{g}$ & $6.1 \mathrm{e}-\mathrm{k}$ \\
\hline HH019 & $1.4 \mathrm{i}-\mathrm{k}$ & $12 \mathrm{jk}$ & $13 \mathrm{~d}-\mathrm{g}$ & $5.2 \mathrm{f}-\mathrm{k}$ \\
\hline B-26 & $1.5 \mathrm{i}-\mathrm{k}$ & $22 \mathrm{~g}-\mathrm{k}$ & $19 \mathrm{c}-\mathrm{g}$ & $4.2 \mathrm{jk}$ \\
\hline HH003 & $1.5 \mathrm{i}-\mathrm{k}$ & $12 \mathrm{i}-\mathrm{k}$ & $15 \mathrm{c}-\mathrm{g}$ & $3.1 \mathrm{k}$ \\
\hline HH004 & $1.5 \mathrm{i}-\mathrm{k}$ & $35 c-j$ & $19 \mathrm{c}-\mathrm{g}$ & $5.1 \mathrm{~g}-\mathrm{k}$ \\
\hline B-31 & $1.6 \mathrm{i}-\mathrm{k}$ & $9 \mathrm{k}$ & $18 \mathrm{c}-\mathrm{g}$ & $4.8 \mathrm{~h}-\mathrm{k}$ \\
\hline B-4 & $1.6 \mathrm{i}-\mathrm{k}$ & $24 \mathrm{f}-\mathrm{k}$ & $27 \mathrm{~b}-\mathrm{g}$ & $6.3 \mathrm{~d}-\mathrm{k}$ \\
\hline HH005 & $1.6 \mathrm{i}-\mathrm{k}$ & $36 c-i$ & $20 \mathrm{c}-\mathrm{g}$ & $11.9 \mathrm{ab}$ \\
\hline HM070007 & $1.7 \mathrm{i}-\mathrm{k}$ & $8 \mathrm{k}$ & $14 \mathrm{c}-\mathrm{g}$ & $4.5 \mathrm{i}-\mathrm{k}$ \\
\hline HM070012 & $1.9 \mathrm{~h}-\mathrm{k}$ & $28 \mathrm{e}-\mathrm{k}$ & $12 \mathrm{~d}-\mathrm{g}$ & $5.7 \mathrm{e}-\mathrm{k}$ \\
\hline HM070015 & $2.0 \mathrm{~h}-\mathrm{k}$ & $30 \mathrm{~d}-\mathrm{k}$ & 38 a-e & $6.8 \mathrm{c}-\mathrm{k}$ \\
\hline B-28 & $2.1 \mathrm{~h}-\mathrm{k}$ & $16 \mathrm{~h}-\mathrm{k}$ & $10 \mathrm{e}-\mathrm{g}$ & $5.0 \mathrm{~g}-\mathrm{k}$ \\
\hline HM070004 & $2.1 \mathrm{~h}-\mathrm{k}$ & $19 \mathrm{~h}-\mathrm{k}$ & $38 \mathrm{a}-\mathrm{e}$ & $4.7 \mathrm{i}-\mathrm{k}$ \\
\hline $\mathrm{C}-21$ & $2.2 \mathrm{~h}-\mathrm{k}$ & $29 \mathrm{e}-\mathrm{k}$ & $30 \mathrm{a}-\mathrm{g}$ & $4.5 \mathrm{i}-\mathrm{k}$ \\
\hline HM070001 & $2.2 \mathrm{~h}-\mathrm{j}$ & $28 \mathrm{e}-\mathrm{k}$ & $41 \mathrm{a}-\mathrm{c}$ & $7.8 c-j$ \\
\hline $\mathrm{C}-2$ & $2.4 \mathrm{~g}-\mathrm{j}$ & $17 \mathrm{~h}-\mathrm{k}$ & $9 \mathrm{fg}$ & $4.6 \mathrm{i}-\mathrm{k}$ \\
\hline HМ070018 & $2.4 \mathrm{~g}-\mathrm{j}$ & $23 \mathrm{~g}-\mathrm{k}$ & $18 \mathrm{c}-\mathrm{g}$ & $5.8 \mathrm{e}-\mathrm{k}$ \\
\hline C-17 & $2.5 \mathrm{~g}-\mathrm{i}$ & $22 \mathrm{~g}-\mathrm{k}$ & $27 \mathrm{~b}-\mathrm{g}$ & $5.8 \mathrm{e}-\mathrm{k}$ \\
\hline SX002 & $2.5 \mathrm{~g}-\mathrm{i}$ & $24 \mathrm{f}-\mathrm{k}$ & $30 \mathrm{a}-\mathrm{g}$ & $5.8 \mathrm{e}-\mathrm{k}$ \\
\hline SX005 & $2.6 \mathrm{f}-\mathrm{i}$ & $18 \mathrm{~h}-\mathrm{k}$ & $6 \mathrm{~g}$ & $13.8 \mathrm{a}$ \\
\hline HH002 & $3.0 \mathrm{e}-\mathrm{h}$ & $18 \mathrm{~h}-\mathrm{k}$ & $11 \mathrm{~d}-\mathrm{g}$ & $5.9 \mathrm{e}-\mathrm{k}$ \\
\hline HM070014 & $3.5 \mathrm{~d}-\mathrm{g}$ & $36 \mathrm{c}-\mathrm{i}$ & $36 \mathrm{a}-\mathrm{f}$ & $5.8 \mathrm{e}-\mathrm{k}$ \\
\hline B-30 & $3.8 \mathrm{c}-\mathrm{f}$ & $54 \mathrm{~b}-\mathrm{d}$ & $58 \mathrm{a}$ & $8.9 \mathrm{~b}-\mathrm{f}$ \\
\hline SX006 & $3.9 \mathrm{c}-\mathrm{e}$ & $58 \mathrm{a}-\mathrm{c}$ & $22 \mathrm{~b}-\mathrm{g}$ & $9.3 \mathrm{~b}-\mathrm{e}$ \\
\hline SX004 & $4.4 \mathrm{~b}-\mathrm{d}$ & $48 \mathrm{~b}-\mathrm{f}$ & $29 \mathrm{~b}-\mathrm{g}$ & $10.4 \mathrm{a}-\mathrm{c}$ \\
\hline HM070011 & $4.8 \mathrm{a}-\mathrm{c}$ & $49 \mathrm{~b}-\mathrm{e}$ & $29 \mathrm{~b}-\mathrm{g}$ & $9.3 \mathrm{~b}-\mathrm{e}$ \\
\hline HM070005 & $4.8 \mathrm{a}-\mathrm{c}$ & $46 \mathrm{~b}-\mathrm{g}$ & $39 a-d$ & $8.7 \mathrm{~b}-\mathrm{g}$ \\
\hline B-16 & $5.0 \mathrm{a}-\mathrm{c}$ & $81 \mathrm{a}$ & $50 \mathrm{ab}$ & $10.0 \mathrm{a}-\mathrm{d}$ \\
\hline SX001 & $5.2 \mathrm{ab}$ & $49 \mathrm{~b}-\mathrm{e}$ & $28 \mathrm{~b}-\mathrm{g}$ & $8.0 \mathrm{c}-\mathrm{i}$ \\
\hline HM070021 & $5.8 \mathrm{a}$ & $62 \mathrm{ab}$ & $28 \mathrm{~b}-\mathrm{g}$ & $8.5 \mathrm{~b}-\mathrm{h}$ \\
\hline Overall mean & 2.7 & 31 & 25 & 7 \\
\hline$P>F^{z}$ & $<0.0001$ & $<0.0001$ & 0.0504 & $<0.0001$ \\
\hline $\operatorname{LSD}(P \leq 0.05)$ & 1.2 & 24 & 28 & 3.8 \\
\hline
\end{tabular}

u All cultivar names were coded (B = Betaseed Inc., C = ACH Seed Inc., HH = Holly Hybrids, HM = Hilleshog, and SX = Seedex), but the respective companies can be contacted using the code to gain additional information on the cultivars.

${ }^{\vee}$ Rhizomania ratings were conducted using a disease index of 0 to $9(0=$ no symptoms, $9=$ root dead $)$. Cultivars contained at least the $R z 1$ gene for resistance to Beet necrotic yellow vein virus except for the susceptible check, HM070005, and cultivars B-16, HM070011, HM070021, SX001, and SX004.

${ }^{\mathrm{w}}$ Fungal growth $=$ percentage of root surface area covered by fungal growth on 1 February 2007. Fungal growth was primarily an undescribed basidiomycete.

${ }^{\mathrm{x}}$ Root rot $=$ percentage of root surface area covered by discolored tissue on 26 February 2007.

${ }^{\mathrm{y}}$ Weight reduction $=$ percent reduction in root weight after storage when compared to that determined at harvest.

${ }^{\mathrm{z}} P>F$ was the probability associated with the $F$ value. Means followed by the same letter did not differ significantly based on Fisher's protected least significant difference (LSD) value with $P \leq 0.05$.

mercial sugar beet pile in Paul, ID for 53 days. The root was then split in half through the plugged area and the distance that discoloration extended from the plug was measured. A $10-\mathrm{mm}$ cubed piece of root from the transition zone (discolored to healthy appearing tissue) was cut from near the plug. The cube was disinfested in $0.6 \%$ sodium hypochlorite $(\mathrm{NaOCl})$ for 60 $s$ and then rinsed in sterilized reverse osmosis water for $60 \mathrm{~s}$. The surface area of each cubed piece was then removed, and a $2 \times 2 \mathrm{~mm}$ piece was placed on PDA amended with streptomycin sulfate at 200 $\mathrm{mg} / \mathrm{liter}$ and incubated at $21^{\circ} \mathrm{C}$. Fungal isolates were identified using a light microscope. The experiment was repeated once.

Data analysis. Data were analyzed in SAS (23) using the general linear models procedure (Proc GLM), and Fisher's protected least significant difference was used for mean comparisons. Correlations based on Spearman's coefficient of rank correlation and linear regression analyses (Proc Reg) were conducted in SAS (23).

\section{RESULTS}

Temperature. During the 2006-2007 indoor storage season, temperatures in the building hit set point of $1.7^{\circ} \mathrm{C}$ on 19 November 2006 (43 days in storage) and maintained temperature until 26 January 2007 (112 days in storage) when temperatures began to rise (Fig. 1A). During the 2006-2007 outdoor storage season, temperatures in the pipe dropped below $0^{\circ} \mathrm{C}$ on 26 November 2006 (50 days in storage) and stayed below zero for 71 of the next 76 days (Fig. 1B). The lowest average daily temperature during this period was $-5.9^{\circ} \mathrm{C}$. During the 2007-2008 indoor storage season, temperatures in the building hit set point on 22 November 2007 (56 days in storage) and maintained temperature until almost the beginning of March 2008 (Fig. 2A). During the 2007-2008 outdoor storage season, temperatures in the pipe dropped below $0^{\circ} \mathrm{C}$ on 21 November 2007 (55 days in storage) and stayed below zero until 23 February 2008 (149 days in storage) except for 5 days (Fig. 2B). The lowest average daily temperature during this period was $-4.4^{\circ} \mathrm{C}$.

Rhizomania ratings. Rhizomania was uniform and significant $(P<0.0001)$ both years (Tables 1 and 2). The mean rating for the susceptible check cultivar, HM070005, was 4.8 in 2006 and 4.5 in 2007. In 2006, the five cultivars (B-16, HM070011, HM070021, SX001, and SX004) lacking the $R z l$ gene all had a rhizomania rating similar to the susceptible check.

Fungal growth. The white cottony fungal growth of a basidiomycete (29) was evident in mid-December both years. By the beginning of February, fungal growth was considerable in both years (Tables 1 and 2). The majority (>95\%) of the fungal growth was the basidiomycete (29), but 
Penicillium spp. and Botrytis spp. were also present on some roots (data not shown). An average of 31 and $45 \%$ of the root surface was covered with fungal growth in 2006 and 2007, respectively. When using Spearman's rank correlation coefficient, fungal growth $(r=0.5608, P=$ $0.0101)$ correlated when comparing the same 20 cultivars included in both studies. Based on regression analysis, a significant positive relationship existed between the rhizomania rating and fungal growth in $2006\left(r^{2}=0.42\right)$, but there was no relationship in $2007\left(r^{2}=0.00\right)$ (Table 3$)$.

Root rot. Root surface rot (discolored tissue) was considerable by the end of the storage season in both years (Tables 1 and 2). In 2006 the rot averaged $25 \%$, but in 2007 it more than doubled to 57\%. In 2006 and 2007, surface rot was related $\left(r^{2}=0.26\right.$ and $r^{2}=0.18$, respectively) to fungal growth on the surface (Table 3). In 2006, there was no difference $(P=0.8591)$ when comparing the six check cultivars indoors (31\%) versus outdoors $(30 \%)$ for root rot. The 2006 outdoor percent rot means for HH004, HH001, HM070005, B-31, B-26, and HM070014 were 40, 34, 30, 27, 26, and 25 , respectively; these means were not significantly different $(P=0.5616)$. Indoors means for the same cultivars were significantly different (Table 1).

In 2007, there was a significant difference $(P=0.0012)$ when comparing the six check cultivars indoors $(64 \%)$ versus outdoors $(50 \%)$ for root rot. The 2007 outdoors percent rot means for HH001, HM070005, HH004, B-26, HM070014, and B-31 were $69,66,62,44,36$, and 24 , respectively; some means were significantly different $(P=0.0074$, LSD $=25)$. Indoors, some means were also significantly different (Table 2). When using Spearman's rank correlation coefficient, root surface rot was not correlated $(r=$ $0.3918, P=0.0876)$ when comparing the same 20 cultivars included in both studies.

Weight reduction. In 2006, root weight was reduced by an average of $7 \%$; whereas in 2007, there was a $19 \%$ reduction (Tables 1 and 2). Indoors, there were significant differences in weight reduction between cultivars as well. In 2006, when comparing the six check cultivars indoors $(6 \%)$ versus outdoors $(17 \%)$ for weight reduction, there was a significant difference $(P=0.0002)$. The 2006 outdoors percent weight reduction means for HM070005, HH001, HH004, HM070014, B-31, and B-26 were $22,18,17,16,15$, and 15 , respectively; some means were significantly different $(P$ $=0.0219, \mathrm{LSD}=4)$. One mean for these cultivars was significantly different indoors (Table 1). In 2007, when comparing the six check cultivars indoors $(20 \%)$ versus outdoors $(13 \%)$ for weight reduction, there was a significant difference $(P=$ 0.0134). The 2007 outdoors percent weight reduction means for B-31, HH001, HM070005, HM070014, HH004, and B-
26 were $16,15,15,13,11$, and 10 , respectively; these means were not significantly different $(P=0.1960)$. Indoors, one mean for these same cultivars was significantly different (Table 2).

Root and sucrose yield. The root yields and estimated recoverable sucrose at harvest were typical for the rhizomania resistant cultivars both years (Tables 4 and 5). Yields for the susceptible check cultivar, HM070005, were considerably reduced as expected. Cultivars were significantly different for these yield data both study years.

Sucrose content and reduction. Sucrose content was significantly different both years among cultivars (Tables 4 and 5). In 2006, when comparing the means for reduction in sucrose with the six check cultivars indoors $(38 \%)$ versus outdoors $(21 \%)$, there was a significant difference $(P=0.0085)$. The 2006 outdoors percent reduction in sucrose means for
HM070005, HH004, HH001, B-31, B-26, and HM070014 were $32,26,20,19,14$, and 13, respectively; these means were not significantly different $(P=0.0906)$. Indoors, some means for these cultivars were significantly different (Table 4). In 2007, when comparing the means for reduction in sucrose with the check cultivars indoors $(88 \%)$ versus outdoors $(45 \%)$, there was a significant difference $(P=0.0016)$. The 2007 outdoor percent reduction in sucrose means for HM070005, HH004, HH001, HM070014, B-31, and B-26 were 60, 58, $54,40,31$, and 28 , respectively; these means were not significantly different $(P=$ 0.0885). Indoors, means for some of the same cultivars were significantly different (Table 4). When comparing the same 20 cultivars included in both studies using Spearman's rank correlation coefficient, sugar reduction results $(r=0.5535, P=$ 0.0114 ) correlated.

Table 2. Disease and weight reduction data for 30 commercial sugar beet cultivars harvested in 2007 from a commercial field naturally infested with rhizomania in Rupert, ID

\begin{tabular}{|c|c|c|c|c|}
\hline Cultivar ${ }^{u}$ & $\begin{array}{c}\text { Rhizomania } \\
\text { rating }^{v}\end{array}$ & $\begin{array}{l}\text { Fungal growth } \\
(\%)^{\mathrm{w}}\end{array}$ & $\begin{array}{l}\text { Root rot } \\
(\%)^{x}\end{array}$ & $\begin{array}{c}\text { Weight } \\
\text { reduction }(\%)^{y}\end{array}$ \\
\hline HH003 & $1.0 \mathrm{e}$ & $64 \mathrm{a}-\mathrm{d}$ & $36 \mathrm{j}-\mathrm{m}$ & $16.4 \mathrm{f}-\mathrm{i}$ \\
\hline HH006 & $1.1 \mathrm{de}$ & $19 \mathrm{f}-\mathrm{i}$ & $21 \mathrm{~m}$ & $16.6 \mathrm{f}-\mathrm{i}$ \\
\hline НМ070007 & $1.2 \mathrm{de}$ & $50 \mathrm{a}-\mathrm{g}$ & $56 c-j$ & $15.9 \mathrm{hi}$ \\
\hline HН008 & $1.2 \mathrm{de}$ & $75 \mathrm{ab}$ & $49 \mathrm{~g}-1$ & $15.8 \mathrm{hi}$ \\
\hline $\mathrm{C}-23$ & $1.3 \mathrm{de}$ & $25 \mathrm{e}-\mathrm{i}$ & $56 \mathrm{c}-\mathrm{j}$ & $17.2 \mathrm{e}-\mathrm{i}$ \\
\hline SX005 & $1.4 \mathrm{de}$ & $19 \mathrm{f}-\mathrm{i}$ & $48 \mathrm{~g}-1$ & $19.2 \mathrm{~b}-\mathrm{h}$ \\
\hline НH011 & $1.4 \mathrm{de}$ & $69 a-c$ & $68 \mathrm{~b}-\mathrm{g}$ & $19.2 \mathrm{~b}-\mathrm{i}$ \\
\hline B-30 & $1.5 \mathrm{de}$ & 60 a-d & $52 \mathrm{e}-\mathrm{k}$ & $21.2 \mathrm{a}-\mathrm{e}$ \\
\hline B-26 & $1.5 \mathrm{de}$ & $38 \mathrm{c}-\mathrm{i}$ & $31 \mathrm{k}-\mathrm{m}$ & $18.1 \mathrm{c}-\mathrm{i}$ \\
\hline HH004 & $1.5 \mathrm{de}$ & $68 \mathrm{a}-\mathrm{d}$ & $79 a-c$ & $21.4 \mathrm{a}-\mathrm{d}$ \\
\hline C-21 & $1.5 \mathrm{de}$ & 50 a-g & $71 \mathrm{a}-\mathrm{g}$ & $20.5 \mathrm{a}-\mathrm{f}$ \\
\hline HН001 & $1.5 \mathrm{de}$ & $82 \mathrm{a}$ & $78 \mathrm{a}-\mathrm{d}$ & $17.6 \mathrm{c}-\mathrm{i}$ \\
\hline B-18 & $1.5 \mathrm{de}$ & $35 \mathrm{~d}-\mathrm{i}$ & $63 \mathrm{~b}-\mathrm{i}$ & $18.2 \mathrm{~b}-\mathrm{i}$ \\
\hline $\mathrm{C}-3$ & $1.6 \mathrm{c}-\mathrm{e}$ & $39 \mathrm{c}-\mathrm{i}$ & $59 c-j$ & $15.0 \mathrm{i}$ \\
\hline $\mathrm{C}-2$ & $1.6 \mathrm{c}-\mathrm{e}$ & $18 \mathrm{~g}-\mathrm{i}$ & $50 \mathrm{f}-1$ & $19.7 \mathrm{~b}-\mathrm{h}$ \\
\hline НМ070004 & $1.6 \mathrm{c}-\mathrm{e}$ & $52 \mathrm{a}-\mathrm{f}$ & $52 \mathrm{e}-\mathrm{k}$ & $18.8 \mathrm{~b}-\mathrm{i}$ \\
\hline НМ070015 & $1.7 \mathrm{~b}-\mathrm{e}$ & $40 \mathrm{c}-\mathrm{i}$ & $66 \mathrm{~b}-\mathrm{h}$ & $22.2 \mathrm{ab}$ \\
\hline SX008 & $1.8 \mathrm{~b}-\mathrm{e}$ & 56 a-e & $52 \mathrm{e}-\mathrm{k}$ & $19.2 \mathrm{~b}-\mathrm{h}$ \\
\hline НМ070001 & $1.8 \mathrm{~b}-\mathrm{e}$ & $14 \mathrm{hi}$ & $42 \mathrm{~h}-\mathrm{m}$ & $17.4 \mathrm{~d}-\mathrm{i}$ \\
\hline B-31 & $1.9 \mathrm{~b}-\mathrm{e}$ & $19 \mathrm{f}-\mathrm{i}$ & $26 \mathrm{~lm}$ & $19.2 \mathrm{~b}-\mathrm{i}$ \\
\hline НH014 & $1.9 \mathrm{~b}-\mathrm{e}$ & $46 \mathrm{~b}-\mathrm{h}$ & $54 \mathrm{~d}-\mathrm{k}$ & $17.1 \mathrm{f}-\mathrm{i}$ \\
\hline НМ070003 & $1.9 \mathrm{~b}-\mathrm{e}$ & $42 \mathrm{~b}-\mathrm{i}$ & 75 a-e & $19.3 \mathrm{~b}-\mathrm{h}$ \\
\hline B-28 & $2.0 \mathrm{~b}-\mathrm{d}$ & $10 \mathrm{i}$ & $38 \mathrm{j}-\mathrm{m}$ & $16.1 \mathrm{~g}-\mathrm{i}$ \\
\hline B-32 & $2.0 \mathrm{~b}-\mathrm{d}$ & $36 \mathrm{c}-\mathrm{i}$ & $40 \mathrm{i}-\mathrm{m}$ & $20.1 \mathrm{a}-\mathrm{g}$ \\
\hline HH005 & $2.0 \mathrm{~b}-\mathrm{d}$ & 58 a-e & $87 \mathrm{ab}$ & $17.5 \mathrm{c}-\mathrm{i}$ \\
\hline НM070014 & $2.0 \mathrm{~b}-\mathrm{d}$ & $54 \mathrm{a}-\mathrm{e}$ & $74 \mathrm{a}-\mathrm{f}$ & $21.7 \mathrm{a}-\mathrm{c}$ \\
\hline B-4 & $2.0 \mathrm{~b}-\mathrm{d}$ & $50 \mathrm{a}-\mathrm{g}$ & $71 \mathrm{a}-\mathrm{g}$ & $18.0 \mathrm{c}-\mathrm{i}$ \\
\hline HH002 & $2.4 \mathrm{bc}$ & $42 \mathrm{~b}-\mathrm{i}$ & $64 \mathrm{~b}-\mathrm{i}$ & 19.7 b-h \\
\hline C-17 & $2.6 \mathrm{~b}$ & $64 a-d$ & $71 \mathrm{a}-\mathrm{g}$ & $16.4 \mathrm{f}-\mathrm{i}$ \\
\hline HМ070005 & $4.5 \mathrm{a}$ & $53 a-f$ & $94 \mathrm{a}$ & $24.2 \mathrm{a}$ \\
\hline Overall mean & 1.8 & 45 & 57 & 19 \\
\hline$P>F^{\mathrm{Z}}$ & $<0.0001$ & 0.0004 & $<0.0001$ & 0.0037 \\
\hline $\operatorname{LSD}(P \leq 0.05)$ & 0.9 & 33 & 25 & 4.2 \\
\hline
\end{tabular}

u All cultivar names were coded (B = Betaseed Inc., C = ACH Seed Inc., HH = Holly Hybrids, HM = Hilleshog, and SX = Seedex), but the respective companies can be contacted using the code to gain additional information on the cultivars.

${ }^{\mathrm{v}}$ Rhizomania ratings were conducted using a disease index of 0 to $9(0=$ no symptoms, $9=$ root dead $)$. All cultivars contained at least the $R z 1$ gene for resistance to Beet necrotic yellow vein virus except for the susceptible check, HM070005.

${ }^{\mathrm{w}}$ Fungal growth $=$ percentage of root surface area covered by fungal growth on 1 February 2008. Fungal growth was primarily an undescribed basidiomycete.

$\mathrm{x}$ Root rot $=$ percentage of root surface area covered by discolored tissue on 4 March 2008.

$\mathrm{y}$ Weight reduction $=$ percent reduction in root weight after storage when compared to that determined at harvest.

${ }^{\mathrm{z}} P>F$ was the probability associated with the $F$ value. Means followed by the same letter did not differ significantly based on Fisher's protected least significant difference (LSD) value with $P \leq 0.05$. 
Table 3. Regression analysis for disease and yield variables in sugar beet storage studies

\begin{tabular}{|c|c|c|c|c|c|}
\hline Independent variable ${ }^{z}$ & $\begin{array}{c}\text { Dependent } \\
\text { variable }\end{array}$ & Slope & Intercept & $r^{2}$ & Probability \\
\hline \multicolumn{6}{|l|}{2006} \\
\hline Fungal growth & ERS & -85 & 8,883 & 0.47 & $<0.0001$ \\
\hline Rz rating & ERS & $-1,187$ & 9,416 & 0.43 & $<0.0001$ \\
\hline $\mathrm{Rz}$ rating & Fungal growth & 0 & 1 & 0.42 & $<0.0001$ \\
\hline Weight reduction & ERS & -479 & 9,503 & 0.34 & $<0.0001$ \\
\hline Fungal growth & Root rot & 0 & 10 & 0.26 & $<0.0001$ \\
\hline Root rot & ERS & -56 & 7,655 & 0.18 & $<0.0001$ \\
\hline Sucrose at harvest & ERS & 1,407 & $-16,266$ & 0.14 & $<0.0001$ \\
\hline Nitrates at harvest & ERS & -6 & 5,356 & 0.01 & 0.0676 \\
\hline Conductivity at harvest & ERS & $-3,780$ & 9,145 & 0.00 & 0.1790 \\
\hline \multicolumn{6}{|l|}{2007} \\
\hline Fungal growth & ERS & -18 & 2,444 & 0.11 & 0.0002 \\
\hline $\mathrm{Rz}$ rating & ERS & -635 & 2,748 & 0.13 & $<0.0001$ \\
\hline $\mathrm{Rz}$ rating & Fungal growth & 0 & 41 & 0.00 & 0.4789 \\
\hline Weight reduction & ERS & -151 & 4438 & 0.11 & 0.0002 \\
\hline Fungal growth & Root rot & 0 & 42 & 0.18 & $<0.0001$ \\
\hline Root rot & ERS & -36 & 3,688 & 0.28 & $<0.0001$ \\
\hline Sucrose at harvest & ERS & 532 & $-6,522$ & 0.06 & 0.0061 \\
\hline Nitrates at harvest & ERS & -1 & 1,936 & 0.01 & 0.4346 \\
\hline Conductivity at harvest & ERS & -262 & 1,802 & 0.00 & 0.8942 \\
\hline
\end{tabular}

${ }^{\mathrm{z}}$ Fungal growth $=$ percentage of root surface area covered by fungal growth. Rz rating $=$ rhizomania rating. Weight reduction $=$ percent reduction in root weight after storage when compared to that determined at harvest. Root rot $=$ percentage of root surface area covered by discolored tissue. ERS = estimated recoverable sucrose at the end of storage.
When comparing the 2006 sucrose reduction with other variables using regression analysis, correlations were as follows: fungal growth $\left(r^{2}=0.47\right)$, rhizomania rating $\left(r^{2}\right.$ $=0.43)$, weight reduction $\left(r^{2}=0.34\right)$, surface rot $\left(r^{2}=0.18\right)$, percent sucrose at harvest $\left(r^{2}=0.14\right)$, nitrates at harvest $\left(r^{2}=\right.$ $0.01)$, and conductivity at harvest $\left(r^{2}=0.00\right)$ (Table 3). When comparing sucrose reduction with the same variables in 2007 , correlations were as follows: surface $\operatorname{rot}\left(r^{2}=\right.$ $0.28)$, rhizomania rating $\left(r^{2}=0.13\right)$, fungal growth $\left(r^{2}=0.11\right)$, weight reduction $\left(r^{2}=\right.$ $0.11)$, percent sucrose at harvest $\left(r^{2}=0.06\right)$, nitrates at harvest $\left(r^{2}=0.01\right)$, and conductivity at harvest $\left(r^{2}=0.00\right)$ (Table 3$)$.

Basidiomycete pathogenicity test. Because the pathogenicity tests did not differ $(P=0.6700)$, variances were homogeneous $(P=0.0859)$, and no interactions were evident $(P>0.28)$, these data were analyzed together. All basidiomycete isolates lead to significant $(P=0.0001)$ rot $(5.6$ to $2.6 \mathrm{~mm}$ ); whereas no rot was evident in the uninoculated check. Isolate F570 produced more rot $(5.6 \mathrm{~mm})$ than the other isolates (3.6 to $2.6 \mathrm{~mm}$ ). Koch's postulates could

Table 4. Yield data for 32 commercial sugar beet cultivars harvested in 2006 from a commercial field naturally infested with rhizomania in Paul, ID

\begin{tabular}{|c|c|c|c|c|c|c|c|}
\hline Cultivar $^{v}$ & $\begin{array}{l}\text { Nitrate } \\
\text { (ppm) }\end{array}$ & $\begin{array}{c}\text { Cond. } \\
(\mathrm{mmhos})^{\mathrm{w}}\end{array}$ & $\begin{array}{c}\text { Sucrose } \\
\text { content }(\%)\end{array}$ & $\begin{array}{c}\text { Root yield } \\
\text { (t/ha) }\end{array}$ & $\begin{array}{l}\text { ERS at harvest } \\
(\mathrm{kg} / \mathrm{ha})^{\mathrm{x}}\end{array}$ & $\begin{array}{c}\text { Sucrose } \\
\text { reduction }(\%)\end{array}$ & $\begin{array}{c}\text { ERS in Feb } \\
(\mathrm{kg} / \mathrm{ha})^{\mathrm{y}}\end{array}$ \\
\hline B-23 & $152 \mathrm{c}-\mathrm{i}$ & $0.74 \mathrm{~d}-\mathrm{i}$ & $16.07 \mathrm{~b}-\mathrm{f}$ & $96.6 \mathrm{a}-\mathrm{c}$ & $13,168 \mathrm{a}-\mathrm{c}$ & $19 \mathrm{gh}$ & $10,629 a$ \\
\hline НH002 & $118 \mathrm{e}-1$ & $0.70 \mathrm{~g}-\mathrm{i}$ & $16.07 \mathrm{~b}-\mathrm{f}$ & $88.8 \mathrm{~d}-\mathrm{j}$ & $12,193 \mathrm{~b}-\mathrm{g}$ & $13 \mathrm{~h}$ & $10,586 \mathrm{a}$ \\
\hline B-26 & $129 \mathrm{~d}-1$ & $0.72 \mathrm{e}-\mathrm{i}$ & $17.01 \mathrm{a}$ & 94.8 a-e & $13,784 \mathrm{a}$ & $26 \mathrm{e}-\mathrm{h}$ & $10,247 \mathrm{ab}$ \\
\hline B-31 & $115 \mathrm{e}-1$ & $0.71 \mathrm{f}-\mathrm{i}$ & $16.95 \mathrm{a}$ & $92.8 \mathrm{~b}-\mathrm{h}$ & $13,447 \mathrm{ab}$ & $24 \mathrm{f}-\mathrm{h}$ & $10,236 \mathrm{ab}$ \\
\hline HМ070007 & $137 \mathrm{c}-1$ & $0.65 \mathrm{i}$ & $16.97 \mathrm{a}$ & $84.3 \mathrm{i}-\mathrm{m}$ & $12,348 \mathrm{~b}-\mathrm{g}$ & $19 \mathrm{gh}$ & $10,013 \mathrm{a}-\mathrm{c}$ \\
\hline B-28 & $202 \mathrm{a}-\mathrm{d}$ & $0.74 \mathrm{~d}-\mathrm{i}$ & $16.33 \mathrm{a}-\mathrm{d}$ & $93.3 \mathrm{~b}-\mathrm{h}$ & $12,939 \mathrm{a}-\mathrm{d}$ & $29 \mathrm{e}-\mathrm{h}$ & 9,312 a-d \\
\hline НH003 & $150 \mathrm{c}-\mathrm{j}$ & $0.73 \mathrm{~d}-\mathrm{i}$ & $15.99 \mathrm{~b}-\mathrm{f}$ & $98.9 \mathrm{ab}$ & $13,430 \mathrm{ab}$ & 31 e-h & 9,240 a-e \\
\hline $\mathrm{C}-21$ & $107 \mathrm{f}-1$ & $0.76 \mathrm{~d}-\mathrm{h}$ & $16.14 \mathrm{~b}-\mathrm{e}$ & $90.8 \mathrm{c}-\mathrm{i}$ & $12,409 \mathrm{~b}-\mathrm{g}$ & $28 \mathrm{e}-\mathrm{h}$ & 8,944 a-f \\
\hline B-4 & $129 \mathrm{~d}-1$ & $0.80 \mathrm{~b}-\mathrm{f}$ & $17.02 \mathrm{a}$ & $89.2 \mathrm{c}-\mathrm{j}$ & 12,791 a-e & 31 e-h & 8,722 a-f \\
\hline C-17 & $188 \mathrm{a}-\mathrm{f}$ & $0.82 \mathrm{~b}-\mathrm{e}$ & $15.70 \mathrm{~d}-\mathrm{g}$ & $92.8 \mathrm{~b}-\mathrm{h}$ & $12,208 \mathrm{~b}-\mathrm{g}$ & 31 e-h & 8,366 a-g \\
\hline НH019 & $244 \mathrm{ab}$ & $0.90 \mathrm{ab}$ & $15.60 \mathrm{~d}-\mathrm{g}$ & 86.3 h-1 & $11,138 \mathrm{~g}-\mathrm{i}$ & 27 e-h & 8,164 a-g \\
\hline B-27 & $148 c-j$ & $0.76 \mathrm{~d}-\mathrm{h}$ & $16.32 \mathrm{a}-\mathrm{d}$ & 94.4 a-f & $13,070 \mathrm{a}-\mathrm{c}$ & $37 \mathrm{~d}-\mathrm{h}$ & 8,110 a-g \\
\hline НМ070012 & $148 \mathrm{c}-\mathrm{j}$ & 0.67 hi & $16.67 \mathrm{ab}$ & $80.01-n$ & $11,472 \mathrm{f}-\mathrm{i}$ & 32 e-h & $7,710 \mathrm{~b}-\mathrm{g}$ \\
\hline C-2 & $151 \mathrm{c}-\mathrm{j}$ & $0.78 \mathrm{c}-\mathrm{g}$ & $16.05 \mathrm{~b}-\mathrm{f}$ & $93.9 \mathrm{a}-\mathrm{g}$ & 12,736 a-f & 40 d-g & $7,700 \mathrm{~b}-\mathrm{g}$ \\
\hline HH005 & $263 \mathrm{a}$ & $0.86 \mathrm{a}-\mathrm{c}$ & $14.74 \mathrm{~h}$ & $100.9 \mathrm{a}$ & $12,353 \mathrm{~b}-\mathrm{g}$ & 39 d-g & $7,663 \mathrm{~b}-\mathrm{g}$ \\
\hline НМ070018 & $187 \mathrm{a}-\mathrm{f}$ & $0.72 \mathrm{~d}-\mathrm{i}$ & $16.56 \mathrm{a}-\mathrm{c}$ & 80.9 k-n & $11,418 \mathrm{~g}-\mathrm{i}$ & $33 \mathrm{e}-\mathrm{h}$ & $7,593 \mathrm{~b}-\mathrm{g}$ \\
\hline HH001 & $138 \mathrm{c}-1$ & $0.82 \mathrm{a}-\mathrm{d}$ & $16.28 \mathrm{a}-\mathrm{d}$ & 95.9 a-d & $13,146 \mathrm{a}-\mathrm{c}$ & 42 d-g & $7,591 \mathrm{~b}-\mathrm{g}$ \\
\hline НМ070004 & $142 \mathrm{c}-\mathrm{k}$ & $0.73 \mathrm{~d}-\mathrm{i}$ & $16.57 \mathrm{a}-\mathrm{c}$ & $86.1 \mathrm{~h}-1$ & $12,174 \mathrm{~b}-\mathrm{g}$ & $38 \mathrm{~d}-\mathrm{g}$ & $7,577 \mathrm{~b}-\mathrm{g}$ \\
\hline HH004 & $218 \mathrm{a}-\mathrm{c}$ & $0.88 \mathrm{ab}$ & $15.41 \mathrm{e}-\mathrm{h}$ & $89.2 c-j$ & $11,393 \mathrm{~g}-\mathrm{i}$ & $36 \mathrm{~d}-\mathrm{h}$ & $7,259 \mathrm{c}-\mathrm{h}$ \\
\hline SX002 & 117 e-1 & $0.69 \mathrm{~g}-\mathrm{i}$ & $16.27 \mathrm{a}-\mathrm{d}$ & $82.7 \mathrm{j}-\mathrm{m}$ & $11,536 \mathrm{e}-\mathrm{i}$ & $37 \mathrm{~d}-\mathrm{h}$ & $7,241 \mathrm{c}-\mathrm{h}$ \\
\hline SX005 & $181 \mathrm{~b}-\mathrm{g}$ & $0.92 \mathrm{a}$ & $15.84 \mathrm{c}-\mathrm{f}$ & $86.5 \mathrm{~g}-1$ & $11,304 \mathrm{~g}-\mathrm{i}$ & $42 \mathrm{~d}-\mathrm{g}$ & $6,601 \mathrm{~d}-\mathrm{h}$ \\
\hline HМ070014 & $105 \mathrm{~g}-1$ & $0.76 \mathrm{~d}-\mathrm{h}$ & $15.03 \mathrm{gh}$ & $81.1 \mathrm{k}-\mathrm{n}$ & $10,298 \mathrm{ij}$ & $38 \mathrm{~d}-\mathrm{g}$ & $6,427 \mathrm{e}-\mathrm{h}$ \\
\hline HМ070015 & $147 \mathrm{c}-\mathrm{k}$ & $0.73 \mathrm{~d}-\mathrm{i}$ & $16.16 \mathrm{~b}-\mathrm{e}$ & $88.1 \mathrm{e}-\mathrm{k}$ & $12,105 \mathrm{c}-\mathrm{g}$ & $49 b-e$ & $6,215 \mathrm{f}-\mathrm{i}$ \\
\hline HМ070001 & 195 a-e & $0.78 \mathrm{c}-\mathrm{g}$ & $16.06 \mathrm{~b}-\mathrm{f}$ & $86.5 \mathrm{~g}-1$ & $11,757 \mathrm{~d}-\mathrm{g}$ & $48 \mathrm{~b}-\mathrm{f}$ & $6,103 \mathrm{f}-\mathrm{i}$ \\
\hline SX006 & $102 \mathrm{~g}-1$ & $0.73 \mathrm{~d}-\mathrm{i}$ & $15.66 \mathrm{~d}-\mathrm{g}$ & $78.5 \mathrm{mn}$ & $10,453 \mathrm{~h}-\mathrm{j}$ & $45 \mathrm{c}-\mathrm{f}$ & $5,776 \mathrm{~g}-\mathrm{j}$ \\
\hline НМ070011 & $69 \mathrm{j}-1$ & $0.75 \mathrm{~d}-\mathrm{i}$ & $15.06 \mathrm{gh}$ & $64.1 \mathrm{pq}$ & $8,210 \mathrm{k}$ & $45 \mathrm{c}-\mathrm{f}$ & $4,515 \mathrm{~h}-\mathrm{k}$ \\
\hline B-30 & $157 \mathrm{c}-\mathrm{h}$ & $0.77 \mathrm{c}-\mathrm{g}$ & $15.90 \mathrm{~b}-\mathrm{f}$ & $87.2 \mathrm{f}-1$ & 11,726 d-h & $70 \mathrm{ab}$ & $3,528 \mathrm{i}-1$ \\
\hline SX001 & $95 \mathrm{~h}-1$ & $0.76 \mathrm{~d}-\mathrm{h}$ & $16.11 \mathrm{~b}-\mathrm{f}$ & $57.8 \mathrm{rq}$ & $7,882 \mathrm{k}$ & $59 \mathrm{~b}-\mathrm{d}$ & $3,170 \mathrm{j}-1$ \\
\hline HМ070005 & 70 i-1 & $0.76 \mathrm{c}-\mathrm{h}$ & $15.36 \mathrm{f}-\mathrm{h}$ & $59.9 \mathrm{rq}$ & $7,765 \mathrm{k}$ & $60 b-d$ & $3,076 \mathrm{j}-1$ \\
\hline SX004 & $145 \mathrm{c}-\mathrm{k}$ & $0.76 \mathrm{c}-\mathrm{h}$ & $15.57 \mathrm{~d}-\mathrm{g}$ & 74.4 no & $9,813 \mathrm{j}$ & $68 \mathrm{a}-\mathrm{c}$ & $3,008 \mathrm{j}-1$ \\
\hline HM070021 & $64 \mathrm{kl}$ & $0.70 \mathrm{f}-\mathrm{i}$ & $15.95 \mathrm{~b}-\mathrm{f}$ & $55.8 \mathrm{r}$ & $7,599 \mathrm{k}$ & $69 \mathrm{a}-\mathrm{c}$ & $2,390 \mathrm{kl}$ \\
\hline B-16 & 581 & $0.80 \mathrm{~b}-\mathrm{f}$ & $14.96 \mathrm{gh}$ & 68.1 op & $8,514 \mathrm{k}$ & $90 \mathrm{a}$ & 8311 \\
\hline Overall mean & 143 & 0.76 & 16.01 & 84.3 & 11,456 & 40 & 7,016 \\
\hline$P>F^{\mathrm{z}}$ & $<0.0001$ & $<0.0001$ & $<0.0001$ & $<0.0001$ & $<0.0001$ & $<0.0001$ & $<0.0001$ \\
\hline LSD & 83 & 0.10 & 0.78 & 7.6 & 1,281 & 24 & 2,853 \\
\hline
\end{tabular}

v All cultivar names were coded $(\mathrm{B}=$ Betaseed Inc., $\mathrm{C}=\mathrm{ACH}$ Seed Inc., HH = Holly Hybrids, HM = Hilleshog, and SX = Seedex $)$, but the respective companies can be contacted using the code to gain additional information on the cultivars.

${ }^{\mathrm{w}}$ Cond. = conductivity during sucrose analysis at harvest.

${ }^{x}$ ERS at harvest $=$ estimated recoverable sucrose at harvest.

y ERS in Feb = estimated recoverable sucrose at the end of storage on 26 February 2007.

${ }^{\mathrm{z}} P>F$ was the probability associated with the $F$ value. Means followed by the same letter did not differ significantly based on Fisher's protected least significant difference (LSD) value with $P \leq 0.05$. 
not be proven with the basidiomycete because only Penicillium spp. and not the basidiomycete were reisolated from the rotted areas.

\section{DISCUSSION}

Cultivar selection for storability using an indoor storage facility gave more consistent significant differences than outdoor storage. By combining the indoor storage approach with roots from an infested rhizomania field, both storability and rhizomania resistance could be addressed at the same time. To perform well in the storage assay, cultivars had to possess both good rhizomania resistance and storability.

Rhizomania has become widespread in the major production areas of the United States and other areas of the world $(21,22,31)$, so developing and maintaining cultivars resistant to BNYVV will be very important to the sugar beet industry. Commercial cultivars currently possess the $R z 1$ gene for resistance to BNYVV, but resistance breaking strains have been discovered in the United States $(1,17)$. Rhizomania can severely impact yield variables in susceptible cultivars but recently has been shown to impact storability as well $(8,28)$. Even by early December in outdoor piles under ambient conditions, infested roots can suffer significant sucrose reductions (28). For roots to perform well in storage, they need resistance to BNYVV as well as storability. Selecting cultivars with improved performance for both traits will be important to the profitability of the sugar beet industry when BNYVV is present in the field.

A basidiomycete (29) was the primary fungus present on the root surface in the storage studies. By the beginning of February, some roots were approaching $100 \%$ coverage by the basidiomycete. The basidiomycete fungal growth was evident on both roots stored outdoors and indoors. The white cottony growth is not very hardy since it desiccates immediately if exposed to dry ambient conditions outside the pile or storage building. Thus, finding this fungus growing as white cottony masses on roots on the surface of an outdoor pile would not be likely. Indoors, this fungus has been frequently found growing on commercial sugar beet roots on the surface of the pile. The basidiomycete has been shown to grow over a range of at least 3 to $22^{\circ} \mathrm{C}(29)$. The optimum temperature for growth has been shown to be between 12 and $16^{\circ} \mathrm{C}$ with no growth occurring at $30^{\circ} \mathrm{C}$ (29). Prior studies have noted the importance of other fungi such as Botrytis, Penicillium spp., Phoma, Fusarium, Rhizopus, and Aspergillus in storage $(5,12,18)$. More research should be conducted to determine if the basidiomycete is pathogenic and what if any interaction it may have with these other fungi.

Based on regression, the basidiomycete was correlated with surface rot and sucrose reduction both years. The basidiomycete fungal growth was correlated with the rhizomania rating in 2006, but in 2007 there was no relationship. The lack of relationship with the rhizomania rating in 2007 may have been affected by the lack of highly susceptible cultivars, other than the susceptible check, and fungal growth and surface rot in storage that bordered on being overwhelming.

If sugar beet roots lose more than 25 to $30 \%$ of their weight, then vital root functions are disrupted and the root cannot resist microbial development $(6,30)$.

Table 5. Yield data for 30 commercial sugar beet cultivars harvested in 2007 from a commercial field naturally infested with rhizomania in Paul, ID

\begin{tabular}{|c|c|c|c|c|c|c|c|}
\hline Cultivar $^{v}$ & $\begin{array}{c}\text { Nitrate } \\
(\mathbf{p p m})\end{array}$ & $\begin{array}{c}\text { Cond. } \\
\text { (mmhos) }^{\mathrm{w}}\end{array}$ & $\begin{array}{c}\text { Sucrose } \\
\text { content }(\%)\end{array}$ & $\begin{array}{c}\text { Root yield } \\
\text { (t/ha) }\end{array}$ & $\begin{array}{l}\text { ERS at harvest } \\
\qquad(\mathrm{kg} / \mathrm{ha})^{\mathrm{x}}\end{array}$ & $\begin{array}{c}\text { Sucrose } \\
\text { reduction }(\%)\end{array}$ & $\underset{(\mathrm{kg} / \mathrm{ha})^{\mathrm{y}}}{\text { ERS in March }}$ \\
\hline НH006 & 223 a-h & 0.716 a-e & $15.04 \mathrm{~h}-\mathrm{k}$ & 98.0 a-e & $12,654 \mathrm{~b}-\mathrm{g}$ & $57 \mathrm{~h}$ & 5,605 a \\
\hline B-31 & $152 \mathrm{f}-\mathrm{i}$ & $0.678 \mathrm{~b}-\mathrm{f}$ & $15.81 \mathrm{~b}-\mathrm{e}$ & $92.4 \mathrm{~d}-\mathrm{h}$ & $12,605 \mathrm{~b}-\mathrm{g}$ & $70 \mathrm{gh}$ & $3,731 \mathrm{ab}$ \\
\hline $\mathrm{C}-3$ & $193 c-i$ & $0.681 \mathrm{~b}-\mathrm{f}$ & $15.67 \mathrm{c}-\mathrm{h}$ & $102.2 \mathrm{a}-\mathrm{d}$ & $13,700 \mathrm{a}-\mathrm{c}$ & $77 \mathrm{e}-\mathrm{g}$ & $3,118 \mathrm{bc}$ \\
\hline HH014 & $127 \mathrm{i}$ & $0.636 \mathrm{~d}-\mathrm{f}$ & $16.63 \mathrm{a}$ & $86.1 \mathrm{gh}$ & $12,369 \mathrm{c}-\mathrm{h}$ & $76 \mathrm{fg}$ & 2,924 b-d \\
\hline HH003 & $290 \mathrm{ab}$ & $0.750 \mathrm{a}-\mathrm{c}$ & $14.87 \mathrm{i}-\mathrm{k}$ & 98.0 b-e & 12,288 e-h & $79 \mathrm{c}-\mathrm{g}$ & 2,664 b-e \\
\hline B-30 & $195 \mathrm{c}-\mathrm{i}$ & $0.700 \mathrm{~b}$-e & $15.20 \mathrm{e}-\mathrm{j}$ & $103.1 \mathrm{a}-\mathrm{c}$ & 13,374 a-f & $81 \mathrm{c}-\mathrm{g}$ & $2,596 \mathrm{~b}-\mathrm{e}$ \\
\hline C-23 & $294 \mathrm{ab}$ & $0.742 \mathrm{a}-\mathrm{c}$ & $15.84 \mathrm{~b}-\mathrm{e}$ & $98.6 \mathrm{a}-\mathrm{e}$ & 13,260 a-g & $81 \mathrm{c}-\mathrm{g}$ & $2,559 \mathrm{~b}-\mathrm{e}$ \\
\hline HM070007 & $181 \mathrm{~d}-\mathrm{i}$ & $0.594 \mathrm{f}$ & $16.33 \mathrm{ab}$ & $84.5 \mathrm{~h}$ & $11,983 \mathrm{gh}$ & $78 \mathrm{~d}-\mathrm{g}$ & $2,526 \mathrm{~b}-\mathrm{e}$ \\
\hline B-28 & $192 \mathrm{c}-\mathrm{i}$ & $0.676 \mathrm{~b}-\mathrm{f}$ & $15.73 \mathrm{~b}-\mathrm{g}$ & $105.8 \mathrm{ab}$ & $14,234 \mathrm{a}$ & $82 \mathrm{~b}-\mathrm{g}$ & $2,521 \mathrm{~b}-\mathrm{e}$ \\
\hline HH008 & $168 \mathrm{e}-\mathrm{i}$ & $0.674 \mathrm{~b}-\mathrm{f}$ & $16.02 \mathrm{a}-\mathrm{d}$ & $92.1 \mathrm{e}-\mathrm{h}$ & $12,648 \mathrm{~b}-\mathrm{g}$ & $82 \mathrm{~b}-\mathrm{g}$ & 2,214 b-f \\
\hline C-2 & 223 a-h & 0.714 a-e & $15.02 \mathrm{i}-\mathrm{k}$ & $104.2 \mathrm{a}-\mathrm{c}$ & $13,303 \mathrm{a}-\mathrm{g}$ & $85 \mathrm{a}-\mathrm{g}$ & 2,049 b-g \\
\hline HM070003 & $138 \mathrm{hi}$ & $0.675 \mathrm{~b}-\mathrm{f}$ & $15.35 \mathrm{e}-\mathrm{i}$ & $97.5 \mathrm{~b}-\mathrm{e}$ & $12,827 \mathrm{~b}-\mathrm{g}$ & $84 \mathrm{~b}-\mathrm{g}$ & $2,048 \mathrm{~b}-\mathrm{g}$ \\
\hline HH002 & $215 \mathrm{~b}-\mathrm{i}$ & $0.657 \mathrm{c}-\mathrm{f}$ & $15.77 b-f$ & $93.3 \mathrm{~d}-\mathrm{h}$ & $12,645 \mathrm{~b}-\mathrm{g}$ & $84 \mathrm{a}-\mathrm{g}$ & 1,949 b-g \\
\hline B-26 & $142 \mathrm{~g}-\mathrm{i}$ & $0.695 \mathrm{~b}-\mathrm{e}$ & $16.13 \mathrm{a}-\mathrm{c}$ & $92.6 \mathrm{~d}-\mathrm{h}$ & 12,987 a-g & $86 \mathrm{a}-\mathrm{g}$ & $1,765 \mathrm{~b}-\mathrm{g}$ \\
\hline HHO04 & $228 \mathrm{a}-\mathrm{h}$ & 0.724 a-e & $15.38 \mathrm{~d}-\mathrm{i}$ & $106.5 \mathrm{ab}$ & $13,919 a b$ & $87 \mathrm{a}-\mathrm{f}$ & 1,744 b-g \\
\hline SX008 & 214 b-i & 0.684 b-f & $15.09 \mathrm{~g}-\mathrm{k}$ & 100.9 a-e & $13,019 \mathrm{a}-\mathrm{g}$ & $88 \mathrm{a}-\mathrm{f}$ & $1,717 \mathrm{~b}-\mathrm{g}$ \\
\hline $\mathrm{C}-21$ & $221 \mathrm{~b}-\mathrm{h}$ & 0.696 b-e & $15.35 \mathrm{e}-\mathrm{i}$ & $101.3 \mathrm{a}-\mathrm{e}$ & $13,260 \mathrm{a}-\mathrm{g}$ & 89 a-f & $1,509 \mathrm{c}-\mathrm{g}$ \\
\hline B-32 & 272 a-d & $0.764 a b$ & $15.07 \mathrm{~h}-\mathrm{k}$ & $107.6 \mathrm{a}$ & 13,666 a-d & 89 a-f & $1,492 \mathrm{c}-\mathrm{g}$ \\
\hline HM070004 & 229 a-h & 0.721 a-e & $15.16 \mathrm{f}-\mathrm{k}$ & $94.8 \mathrm{c}-\mathrm{g}$ & 12,217 e-h & 90 a-f & $1,348 \mathrm{c}-\mathrm{g}$ \\
\hline SX005 & $242 \mathrm{a}-\mathrm{f}$ & $0.730 \mathrm{a}-\mathrm{d}$ & $14.92 \mathrm{i}-\mathrm{k}$ & $104.2 \mathrm{a}-\mathrm{c}$ & $13,192 \mathrm{a}-\mathrm{g}$ & 90 a-f & $1,300 \mathrm{c}-\mathrm{g}$ \\
\hline НH005 & $315 \mathrm{a}$ & $0.752 \mathrm{a}-\mathrm{c}$ & $14.68 \mathrm{jk}$ & $101.8 \mathrm{a}-\mathrm{d}$ & $12,625 \mathrm{~b}-\mathrm{g}$ & 89 a-f & $1,265 \mathrm{c}-\mathrm{g}$ \\
\hline HM070001 & 254 a-e & 0.719 a-e & $14.66 \mathrm{jk}$ & $102.2 \mathrm{a}-\mathrm{d}$ & $12,712 \mathrm{~b}-\mathrm{g}$ & $92 \mathrm{a}-\mathrm{f}$ & $1,094 \mathrm{c}-\mathrm{g}$ \\
\hline C-17 & $232 \mathrm{a}-\mathrm{g}$ & $0.722 \mathrm{a}-\mathrm{e}$ & $15.32 \mathrm{e}-\mathrm{i}$ & 99.8 a-e & $12,986 \mathrm{a}-\mathrm{g}$ & $92 \mathrm{a}-\mathrm{e}$ & $1,029 \mathrm{~d}-\mathrm{g}$ \\
\hline HH011 & $169 \mathrm{e}-\mathrm{i}$ & $0.678 \mathrm{~b}-\mathrm{f}$ & $15.67 \mathrm{c}-\mathrm{h}$ & 100.9 a-e & 13,529 a-e & 93 a-d & $937 \mathrm{~d}-\mathrm{g}$ \\
\hline HM070014 & $186 \mathrm{c}-\mathrm{i}$ & $0.658 \mathrm{c}-\mathrm{f}$ & $14.65 \mathrm{jk}$ & $87.6 \mathrm{f}-\mathrm{h}$ & $11,082 \mathrm{~h}$ & $92 \mathrm{a}-\mathrm{f}$ & $927 \mathrm{~d}-\mathrm{g}$ \\
\hline B-4 & $158 \mathrm{f}-\mathrm{i}$ & 0.718 a-e & $15.24 \mathrm{e}-\mathrm{j}$ & $101.8 \mathrm{a}-\mathrm{d}$ & $13,211 \mathrm{a}-\mathrm{g}$ & 94 a-d & $817 \mathrm{e}-\mathrm{g}$ \\
\hline HH001 & $274 \mathrm{a}-\mathrm{c}$ & $0.805 \mathrm{a}$ & $14.54 \mathrm{k}$ & 100.9 a-e & $12,309 \mathrm{~d}-\mathrm{h}$ & $94 \mathrm{a}-\mathrm{c}$ & $653 \mathrm{e}-\mathrm{g}$ \\
\hline B-18 & $207 \mathrm{~b}-\mathrm{i}$ & 0.629 ef & $15.42 \mathrm{~d}-\mathrm{i}$ & 100.9 a-e & 13,446 a-e & $97 \mathrm{ab}$ & $309 \mathrm{fg}$ \\
\hline HM070005 & $242 \mathrm{a}-\mathrm{f}$ & $0.734 \mathrm{a}-\mathrm{d}$ & 13.471 & $64.1 \mathrm{i}$ & $7,395 \mathrm{i}$ & $100 \mathrm{a}$ & $0 \mathrm{~g}$ \\
\hline НМ070015 & $264 \mathrm{a}-\mathrm{d}$ & $0.753 \mathrm{a}-\mathrm{c}$ & $14.84 \mathrm{i}-\mathrm{k}$ & $96.2 \mathrm{c}-\mathrm{f}$ & $12,044 \mathrm{f}-\mathrm{h}$ & $100 \mathrm{a}$ & $0 \mathrm{~g}$ \\
\hline Overall mean & 215 & 0.702 & 15.30 & 97.5 & 12,709 & 86 & 1,814 \\
\hline$P>F^{\mathrm{z}}$ & 0.0028 & 0.0468 & $<0.0001$ & $<0.0001$ & $<0.0001$ & 0.0004 & 0.0007 \\
\hline LSD & 92 & 0.098 & 0.64 & 9.6 & 1,378 & 16 & 2,085 \\
\hline
\end{tabular}

${ }^{\mathrm{v}}$ All cultivar names were coded (B = Betaseed Inc., C = ACH Seed Inc., HH = Holly Hybrids, HM = Hilleshog, and SX = Seedex), but the respective companies can be contacted using the code to gain additional information on the cultivars.

${ }^{\mathrm{w}}$ Cond. $=$ conductivity during sucrose analysis at harvest.

${ }^{\mathrm{x}}$ ERS at harvest $=$ estimated recoverable sucrose at harvest.

${ }^{y}$ ERS in March $=$ estimated recoverable sucrose at the end of storage on 4 March 2008.

${ }^{\mathrm{z}} P>F$ was the probability associated with the $F$ value. Means followed by the same letter did not differ significantly based on Fisher's protected least significant difference (LSD) value with $P \leq 0.05$. 
Weight reduction was significant in both years, but mean values were less than $25 \%$, so roots should have retained the ability to resist microbial development.

During both storage seasons, the outdoor piles afforded excellent storage conditions. The weather turned cold in early December and the average daily temperature stayed below $0^{\circ} \mathrm{C}$ most of the winter, thus creating ideal outdoor storage conditions. Root sucrose reduction within the outdoor piles was less than that on the surface of the indoor piles both years. Similar sucrose reduction data were collected in Idaho in 1978 when samples in controlled storage lost more sucrose than those in outdoor piles (20). However, during storage seasons when prolonged periods of warm wet weather follow freezing weather, storing sugar beet roots in outdoor piles can be much more challenging than the conditions during the 2006-2007 and 2007-2008 storage seasons.

In previous studies, sucrose was lost at the rate of 0.2 to $0.5 \mathrm{lb}$ per ton of sugar beet roots per day $(9,20)$. Based on these data, sugar companies could expect to lose from 8 to $17 \%$ of their sucrose in 100 days with healthy roots under good storage conditions in an outdoor pile. Because our studies were conducted for 142 and 159 days, we expected to lose at least 11 to $27 \%$ of the sucrose. Our sucrose losses ranged from 13 to $90 \%$ in 2006 and 57 to $100 \%$ in 2007 indoors, and from 13 to $32 \%$ in 2006 and 28 to $60 \%$ in 2007 outdoors. These data should not be considered surprising given that the roots were compromised by BNYVV, fungal growth, and surface rot. Regression data indicated that fungal growth, rhizomania rating, weight reduction, and surface rot were all related to sucrose reduction both years. The percentage of variation explained by these regression data changed between years; thus additional research will be required to identify which variable may be most important over time.

Previous studies have shown that if $20 \%$ or more of the root surface is affected by fungal growth, root respiration increases $100 \%$ (18). Indoors, the root surface was covered with an average of 31 and $45 \%$ in 2006 and 2007, respectively. The rank correlations for fungal growth $(r=0.56)$ and sugar reduction $(r=0.55)$ between years were significant. These data show that even though fungal growth and sucrose reduction varied between years, the ranking of the cultivars between years for these traits was similar. In previous storage work outdoors (28) and indoors (25) without the influence of disease, establishing significant differences between cultivars for reduction in sucrose was not possible. When utilizing rhizomania-infested sugar beet roots, significant differences in su- crose reduction and estimated recoverable sugar were possible both years. Cultivars that performed well possessed both storability and rhizomania resistance. Thus, the indoor storage approach with rhizomania-infested roots should allow for reliable separation and ranking of sugar beet cultivars for storability and rhizomania resistance.

\section{ACKNOWLEDGMENTS}

These data support the objectives for the United States Department of Agriculture CRIS project 5368-21220-003-00D. We thank the Amalgamated Sugar Co., Amalgamated Res. Inc., Beet Sugar Development Foundation, and Snake River Sugar Beet Growers for supporting our research work.

\section{LITERATURE CITED}

1. Acosta-Leal, R., Fawley, M. W., and Rush, C. M. 2008. Changes in the intraisolate genetic structure of Beet necrotic yellow vein virus populations associated with plant resistance breakdown. Virology 376:60-68.

2. Akeson, W. R., and Stout, E. L. 1978. Effect of the impact damage on sucrose loss in sugarbeets during storage. J. Am. Soc. Sugar Beet Technol. 20:167-173.

3. Akeson, W. R., and Widner, J. N. 1981. Differences among sugarbeet cultivars in sucrose loss during storage. J. Am. Soc. Sugar Beet Technol. 21:80-91.

4. Bartens, A. 2005. International Commission for Uniform Methods of Sugar Analysis Methods Book 2005. Dr. Albert Bartens KG, Berlin.

5. Bugbee, W. M. 1982. Storage rot of sugar beet. Plant Dis. 66:871-873.

6. Bugbee, W. M. 1993. Storage. Chapter 14 in: The Sugar Beet Crop: Science into Practice. D. A. Cooke and R. K. Scott, eds. Chapman and Hall, London.

7. Campbell, L. G., and Klotz, K. L. 2006. Postharvest storage losses associated with Aphanomyces root rot in sugarbeet. J. Sugar Beet Res. 43:113-127.

8. Campbell, L. G., Klotz, K. L., and Smith, L. J. 2008. Postharvest storage losses associated with rhizomania in sugar beet. Plant Dis. 92:575-580.

9. Cole, D. F., and Bugbee, W. M. 1976. Changes in resident bacteria, $\mathrm{pH}$, sucrose, and invert sugar levels in sugarbeet roots during storage. Appl. Environ. Microbiol. 31:754-757.

10. Dexter, S. T., Frakes, M. G., and Nichol, G. 1966. The effect of low, medium and high nitrogen fertilizer rates on the storage of sugar beet roots at high and low temperatures. J. Am. Soc. Sugar Beet Technol. 14:147-159.

11. Finkner, R. E., Finkner, M. D., and Olson, R. F. 1959. Effects of storage on raffinose content of sugar beets I. Varietal changes occurring during storage. J. Am. Soc. Sugar Beet Technol. 10:481-488.

12. Karnik, V. V., Olson, L. E., Salunkhe, D. K., and Singh, B. 1970. Evaluation of effects of controlled atmosphere storage on roots of sugarbeets grown at various levels of nitrogen fertilizer. J. Am. Soc. Sugar Beet Technol. 16:225-234.

13. Kenter, C., and Hoffman, C. 2006. Changes in the quality of frost-damaged sugarbeet during storage as affected by temperature and variety. Sugar Industry 131:85-91.

14. Kenter, C., and Hoffman, C. 2008. Influence of drought stress on quality and storage properties of sugarbeet. Sugar Industry 133:155-160.

15. Kenter, C., Hoffmann, C., and Märländer, B. 2006. Sugarbeet as raw material - Advanced storage management to gain good processing quality. Sugar Industry 131:706-720.

16. Klotz, K. L., and Finger, F. L. 2004. Impact of temperature, length of storage, and postharvest disease on sucrose catabolism in sugarbeet. Postharv. Biol. Technol. 34:1-9.

17. Liu, H.-Y., Sears, J. L., and Lewellen, R. T. 2005. Occurrence of resistance-breaking Beet necrotic yellow vein virus of sugar beet. Plant Dis. 89:464-468.

18. Mumford, D. L., and Wyse, R. E. 1976. Effect of fungus infection on respiration and reducing sugar accumulation of sugarbeet roots and use of fungicides to reduce infection. J. Am. Soc. Sugar Beet Technol. 19:157-162.

19. Peterson, C. L., Hall, M. C., and Traveller, D. J. 1984. Sugarbeet storage experiments. ASAE Pap. No. 84-4040. ASAE, Knoxville, TN.

20. Peterson, C. L., Traveller, D. J., and Hall, M. C. 1980. Loss of sucrose during controlled and conventional storage. J. Am. Soc. Sugar Beet Technol. 20:517-530.

21. Rush, C. M. 2003. Ecology and epidemiology of Benyviruses and Plasmodiophorid vectors. Annu. Rev. Phytopathol. 41:567-592.

22. Rush, C. M., Liu, H.-Y., Lewellen, R. T., and Acosta-Leal, R. 2006. The continuing saga of rhizomania of sugar beets in the United States. Plant Dis. 90:4-15.

23. SAS Institute, Inc. 2002. The SAS system for Windows. Version 9.1.3. SAS Institute Inc., Cary, NC.

24. Smith, G. A., and Ruppel, E. G. 1971. Cercospora leaf spot as a predisposing factor in storage rot of sugar beet roots. Phytopathology 61:1485-1487.

25. Strausbaugh, C. A., Eujayl, I. A., Rearick, E., and Foote, P. 2008. Sugar beet cultivars evaluated for storability in Idaho during the 2006/2007 storage season. Plant Disease Management Reports (online) Report 2:FC022. DOI:10.1094/PDMR02. American Phytopathological Society, St. Paul, MN.

26. Strausbaugh, C. A., Gillen, A. M., Gallian, J. J., Camp, S., and Stander, J. R. 2006. Influence of host resistance and insecticide seed treatments on curly top in sugar beets. Plant Dis. 90:1539-1544.

27. Strausbaugh, C. A., Rearick, E., and Camp, S. 2008. Influence of curly top and Poncho Beta on storability of sugarbeet. J. Sugar Beet Res. 45:31-47.

28. Strausbaugh, C. A., Rearick, E., Camp, S., Gallian, J. J., and Dyer, A. T. 2008. Influence of Beet necrotic yellow vein virus on sugar beet storability. Plant Dis. 92:581-587.

29. Toda, T., Strausbaugh, C. A., Vilgalys, R., and Cubeta, M. A. 2008. Characterization of basidiomycete fungus from sugarbeet in Idaho. (Abstr.) Inoculum 59:59.

30. Vajna, S. 1962. Zuckerruben-Lagerung. Albert Bartens, Berlin. pp. 200-202.

31. Ward, L., Koenig, R., Budge, G., Garrido, C. McGrath, C., Stubbley, H., and Boonham, N. 2007. Occurrence of two different types of RNA-5-containing beet necrotic yellow vein virus in the UK. Arch. Virol. 152:59-73.

32. Wisler, G. C., Lewellen, R. T., Sears, J. L., Liu, H.-Y., and Duffus, J. E. 1999. Specificity of TAS-ELISA for beet necrotic yellow vein virus and its application for determining rhizomania resistance in field-grown sugar beets. Plant Dis. 83:864-870.

33. Wyse, R. E. 1978. Effect of low and fluctuating temperatures on the storage life of sugarbeets. J. Am. Soc. Sugar Beet Technol. 20:33-42.

34. Wyse, R. E., and Dexter, S. T. 1971. Source of recoverable sugar losses in several sugarbeet varieties during storage. J. Am. Soc. Sugar Beet Technol. 16:390-398. 